\title{
Protests under Occupation: The Spring inside Western Sahara
}

Irene Fernández-Molina

European Neighbourhood Policy Chair, College of Europe, Natolin Campus

Nowoursynowska 84 02-797 Warsaw, Poland

(+48) 225459751

irene.fernandez@coleurope.eu

\section{Abstract:}

The emergence and empowerment of Sahrawi civil protests and pro-independence activism inside the Western Sahara territory under Moroccan occupation have to be seen in the context of varying sets of opportunity structures which this peripheral movement has actively seized in the past two decades by symbiotically combining domestic nonviolent resistance and international 'diplomatic' activities. Different forms of recognition received from the two reference centres - the Moroccan state and the Polisario Front - plus the international community have been crucial in this process, with the last representing the most significant achievement of the movement. The Arab Spring has been a particularly fruitful window of opportunity in this regard. Building on comparatively rich mobilization structures at local, inter-Sahrawi, Moroccan and international level, Sahrawis have successfully been able to frame the local Gdeim Izik protest in a favourable universalistic paradigm which has enhanced their international standing, while opportunities have broadened relatively also at Moroccan state level.

Key words:

Western Sahara; civil protest; social movements; centre-periphery relations; recognition; Arab Spring 
Sahrawi civil protests in the Western Sahara territory under Moroccan control intensified just before the Arab Spring broke out in Tunisia. Indeed, the Sahrawi protest camp set up at Gdeim Izik, Laayoune, in October-November 2010 was described by some observers in hindsight as the first chapter of the Arab uprisings (Errazzouki, 2012). Not only was this protest based on the physical occupation of a public space in a nonviolent but resolute way ('occupy' tactic) (Dann, 2014), but also the demands made brought together socioeconomic grievances and an all-encompassing nonmaterial call for 'dignity' ('karama') in a similar manner to other Arab Spring revolts. Nonetheless, there were also quite distinctive features resulting from a context of mixed decolonization and identity conflict, ${ }^{i}$ along with Moroccan occupation of the territory. These peculiarities included the Sahrawi nationalist framing that was to be gradually imposed on events and the camp's distance from the city centre of Laayoune, where the level of security control would have never allowed it to have been established. The unique political environment of Western Sahara certainly shaped an 'Arab Spring of a different kind' (Pace, 2013), in which popular demands for dignity, justice and freedom revolved more around the consequences of the protracted conflict than around primarily antiauthoritarian claims.

This Sahrawi protest appears to be evidently peripheral in three ways. Besides being marginal in both geographical and political terms - physically remote from any plausible state/regional 'centre' and usually out of the international media's focus and political agenda - it remains exceptional because of the persistent constraints inflicted by protracted conflict and occupation. Hence both distance and difference (Huber and Kamel, this volume) feature prominently in this periphery. At the same time, it should be noted that the centre of gravity of the conflict has gradually shifted 'inwards' over the last two decades: from the international/diplomatic arena - the UN-led negotiations between Morocco and the exiled Polisario Front ${ }^{\mathrm{ii}}$ - to the disputed land where it started, that is the now Moroccanoccupied territory, where the Sahrawi population has been transformed over the years into a demographic minority. The Arab Spring period represents the latest, albeit unique, phase in this process.

What seems somehow more problematic to establish is in relation to which specific centre(s) this periphery has defined itself and constructed its identity over years. This is a crucial question because of the inherently relational and relative nature of the notions of centre and periphery, which are dependent on interaction and also subject to change (Huber and Kamel, this volume). Unlike other territorial peripheries studied in this special issue which define themselves in relation to a distinct state centre (Suárez Collado, this volume) or a set of concentric circles (Bergh and Rossi-Doria, this volume), the protest actors inside Western Sahara have built their political identity and struggle upon relations and transactions with two disparate - and indeed opposed - centres: Rabat and Tindouf, i.e. the capital of the occupying and administering state and the refugee camps in south-western Algeria where pro-independence Polisario Front established its headquarters and proclaimed the Sahrawi Arab Democratic Republic (RASD) in exile in 1976. Moreover, both of these centre-periphery relationships are dynamic structures: the intensity and content of interactions which determine distance in each of them have varied since the start of the conflict. Administrative and economic dependence on the Rabat centre has not prevented distance from the Tindouf centre from being reduced in terms of communication and political identity over the last two decades.

This article tries to understand how the 'inward turn' of the conflict was achieved by proindependence Sahrawi activists operating inside the occupied territory; in other words, how such a politically peripheral community - even in the context of the Sahrawi camp - was able to become relatively empowered and central to the conflict. From the viewpoint of these actors, this counterhegemonic process can be analyzed as a struggle for recognition (Taylor, 1994; Honneth, 1996) vis-àvis three significant others: the two reference centres - the Moroccan state (Rabat) and the Polisario Front (Tindouf) - plus the international community. Thus, the argument put forward is that the empowerment of this periphery was made possible not only by variations in the opportunity 
structure, mainly at the Moroccan state level, which were actively seized by the internal Sahrawi activists ${ }^{\text {iii }}$ through a novel combination of domestic nonviolent resistance and international 'diplomatic' activism, but also that the recognition achieved through these strategies was crucial in this process.

Research has tended to overlook the central issue of recognition. While some recent works have focused on Sahrawi nonviolent resistance (Stephan and Mundy, 2006; Mundy and Zunes, 2014; Dann, 2014), they have not fully disentangled two aspects: first, the role played by Morocco's partial and flawed recognition policies in enabling and fuelling such activism and, second, the symbiotic relationship between this domestic struggle and recognition from the international community, which is the necessary 'mirror' which has allowed it to come into existence and gain significance. This article therefore argues that the achievements of internal Sahrawi activists should be assessed primarily in terms of recognition. The Arab Spring context, in the wake of the local protest of Gdeim Izik, was particularly conducive to this process as it broadened opportunities at Moroccan state level while reviving the international community's interest in human rights in Western Sahara.

In addition to social movement theory (McAdam, McCarthy and Zald, 1996: 1-17; Tarrow, 2003: 1925 ) and Eduard Azar's theory of 'protracted social conflict' (1990), these arguments draw on Hegelinspired theories of recognition, which underscore how any individual or collective agent depends on social interaction with (and feedback from) other subjects in order to gain self-consciousness, that is to create and preserve its own identity. Self-descriptions or self-interpretations always need to be acknowledged and validated by external others. Alongside (1) the most elementary sense of recognition as acknowledgement of an agent's very existence and distinct identity (cognitive recognition), this strand of literature distinguishes between three key psychological or emotional dimensions: (2) respect (recognition of equal status and rights), (3) esteem (recognition of difference) and (4) empathy (recognition through understanding and affection) (Taylor, 1994; Honneth, 1996; Thompson, 2006; Lindemann and Ringmar, 2012: 7). Thomas Lindemann further adds an instrumental or strategic component found in cases in which recognition entails some kind of material advantages (2010: 2-3) - which is also reminiscent of Nancy Fraser's emphasis on the connection between recognition and redistribution (Fraser and Honneth, 2003).

The bulk of the fieldwork for this article was conducted in June 2013 in a 'peripheral centre' (Huber and Kamel, this volume): the city of Laayoune, which is the capital of the territory under occupation, remains largely isolated and is hardly accessed by foreigners. This is, on the one hand, a particularly unfavourable and under-researched environment (Zunes and Mundy, 2010: xxxiii) where the movements and contacts of any visitor are constantly controlled by the Moroccan security services, while widespread fear and paranoia among the local population (of all political leanings) create a tense and charged atmosphere. On the other hand, Sahrawi activists are extremely welcoming and eager to meet any external observer or supporter as a result of their political strategy and pressing need for recognition. The work mainly involved semi-structured individual or group interviews with representatives from some ten independent Sahrawi civil society organizations based in this city, most of who broadly supported the independence of Western Sahara.

This article is structured as follows. The first section will place the Sahrawi 'Arab Spring' in the context of a continuously evolving inward-shift of the conflict. It will show how changing opportunity structures - specifically five windows of opportunity of which the Arab Spring represents the latest were seized by internal Sahrawi activists. The second section will then turn to a deeper examination of how Sahrawi strategies capitalized on existing mobilization structures at local, inter-Sahrawi, Moroccan and international level during the Arab Spring. It will show that, in contrast to other peripheries treated in this volume, these comparably developed mobilization structures enabled internal Sahrawi activists to achieve a relatively important subjective outcome. This result is discussed 
in the concluding section, stressing the relevance of the recognition obtained from the Moroccan state, the Polisario Front and the international community.

\section{Changing opportunity structures and the Sahrawi 'Arab Spring'}

Five windows of opportunity can be identified within the chronology of the internal Sahrawi proindependence movement, which Sahrawi activists have seized over the last three decades. The Arab Spring was the last of them, and while it might not necessarily have been the most important, it provided unique opportunities for a transforming Sahrawi activism. While the contingent empowerment of Sahrawi activism has been facilitated in each phase mainly by different recognition policies of the occupying state, the exceptional feature of the aftermath of the latest protest cycle has been the relative easing of the level of Moroccan repression, accompanied by a revived interest on the part of the international community in human rights in Western Sahara.

\section{A short chronology of a conflict shifting 'inside': 1991, 1999, 2004, 2009}

The situation in the occupied Western Sahara territory in the 1980s and even the 1990s was one of virtual isolation, including a deep disconnect between Sahrawis who had remained there and the Tindouf centre of pro-independence struggle: 'This created a real break-up. We had a society that was divided into two and each part evolved separately' (Interview III, 2013). However, a first window of opportunity opened at the beginning of the 1990s, facilitated by the UN-sanctioned ceasefire and Settlement Plan (1991) accepted by Morocco and the Polisario Front, which provided for a referendum on self-determination, as well as a state-wide process of political liberalization launched by the Rabat authorities. Although it was a far cry from genuine democratization, the significant broadening of civil liberties and expansion of the public space witnessed in the 1990s did have a tangible impact on the development of civil society in Morocco and, albeit in a far more limited and slower way, in occupied Western Sahara.

This mix of factors led to two novel developments on the ground. First, UN involvement in the conflict and the mere establishment of the UN Mission for the Referendum in Western Sahara (MINURSO) in Laayoune encouraged a part of the Sahrawi population that had stayed silent under Moroccan occupation to express its grievances timidly. Second, in June 1991, a number of Sahrawi political prisoners and 'disappeared' were for the first time released - and thus acknowledged to exist, entailing recognition by the Moroccan regime in the most elementary sense. Some of them seized the opportunity of a 'fully transformed social context' (Gimeno, 2013: 13) and created informal groups, which merged into the so-called Coordination Committee of Sahrawi Victims of Enforced Disappearances in 1994. Furthermore, first attempts at networking with Moroccan and international actors started with a clandestine expedition from this periphery to the Rabat centre (Martín Beristain and González Hidalgo, 2012, vol. 2: 229, 444).

A second window of opportunity related to changes in the Rabat centre opened in the run-up to the succession to the throne in 1999, which was surrounded by an all-pervasive discourse of change and had a deep impact on the perceptions of political opportunities: 'I think this opening-up exists. Mohammed VI is not Hassan II, it must be said. If we say that both are the same, it means that we are not "historical"' (Interview III, 2013). Memory policies and redress for human rights abuses during the 'years of lead' ${ }^{\text {iv }}$ took centre stage in the promised 'democratic transition' and unleashed unintended dynamics within Moroccan civil society. At the same time, after the historic wave of protests which started in Laayoune in the autumn of 1999, when the disproportionate repression of a peaceful sit-in by Sahrawi students expressing social demands led to violent riots lasting several weeks (Shelley, 2004: 115-121; Smith, 2005: 557; Stephan and Mundy, 2006: 11-13), a new era of appeasement and conciliation with the Sahrawi population was announced, coinciding with King Mohammed VI's tacit disengagement from the Settlement Plan roadmap. The idea of a 'third way' (autonomy under 
Moroccan sovereignty) towards the resolution of the conflict also made headway in Moroccan society. In sum, the Sahrawis were the target of unprecedented recognition measures in the sense of both respect (equal rights) and esteem (difference).

Within this climate, the Forum for Truth and Justice (FVJ), founded in 1999 by the most militant Moroccan human rights defenders, was unprecedentedly open to Sahrawi activists. This initiative of independent civil society within the Rabat centre had a significant impact on the Western Sahara periphery and on centre-periphery relations. In August 2000 a Sahara Section of the FVJ was established in Laayoune, thus becoming the first formal, fully operational and legal independent civil society organization in the occupied territory to be made up of Sahrawis, simply 'because the FVJ was an association of victims, that is the difference' (Interview III, 2013). ${ }^{v}$ In parallel, also strictly Sahrawi groups continued to arise, seizing the opportunity. The Coordination Committee sent a vanguard group to Rabat in 1998 to build networks with representatives of foreign embassies and some Moroccan media, political parties and civil society organizations (Interview VI, 2013) and, one year later, submitted a joint application detailing some 1,200 files of human rights violations to the Independent Arbitration Committee set up by Mohammed VI (Martín Beristain and González Hidalgo, 2012, vol. 2: 267-269).

The third turning point in the evolution of the internal Sahrawi pro-independence movement came in 2003 at a particularly critical juncture at the diplomatic level when the Moroccan regime rejected the Baker Plan II, ${ }^{\mathrm{vi}}$ which was interpreted as a sign of its fear that the independence option might win in a final referendum (Hernando de Larramendi, 2008: 191-192; Le Journal Hebdomadaire, 8-14 November 2003). The acceptance of this plan by the Polisario Front turned the tables (Zoubir and Benabdallah-Gambier, 2004: 68) and placed Rabat in the awkward position of being seen as a 'spoiler' by the international community. From this moment onwards, Morocco changed strategy and started openly to promote a permanent autonomy solution that excluded the holding of a selfdetermination referendum. This substitute step towards recognition of Sahrawi difference within a Moroccan state framework was coupled with a more supposedly equal cross-Moroccan form of recognition of rights, namely the establishment of a widely publicized Equity and Reconciliation Commission (IER) in 2004. However, in the end the gap between the victims' expectations and the results of this flawed experience of 'transitional justice' proved to be large (Suárez Collado, this volume), especially for the Sahrawis who accounted for 23 per cent of complainants, and a precious opportunity for recognition was lost: 'We were treated like numbers' (Interview VI, 2013). ${ }^{\text {vii }}$

The reaction by Sahrawi victims/activists to this new and paradoxical opportunity structure enabled by the Rabat centre was to create the Sahrawi Association of Victims of Gross Human Rights Violations Committed by the Moroccan State (ASVDH) in early May 2005, as well as strong protests and riots which came to be called the Sahrawi 'Intifada'. viii Apart from its magnitude in terms of participation, extension over time and geographical scope, what made this protest cycle in the Western Saharan periphery different was the open use of pro-independence symbols and slogans and the unusual degree of attention received from the international media (Gimeno, 2013: 23). Both novelties were crucial for the elementary cognitive recognition of internal Sahrawi groups by the two significant others besides Morocco: the Polisario Front (the Tindouf centre) and the international community. In face of this, the Rabat centre chose to resume and upgrade the previous combination of the autonomy roadmap plus the spirit of 'reconciliation' (recognition of difference) by establishing a Royal Consultative Council for Saharan Affairs (CORCAS), which drafted a formal Autonomy Plan for Western Sahara. ${ }^{\text {ix }}$ On the ground, the post-'Intifada' stage was characterized by a relative decrease in repression and diminution in the isolation of the occupied territory as a result of the activists' growing use of new technologies and media, more frequent visits by foreign observers or supporters, as well as invitations to prominent internal Sahrawi leaders to participate in events abroad - the last constituting indications of recognition in the form of empathy. In October 2007, some figures from this well-connected associative elite (and former members of the dissolved FVJ-Sahara) officially 
founded the Collective of Sahrawi Defenders of Human Rights (CODESA), which would subsequently become a key organization (Interview X, 2013).

In 2009, two changes at international level opened up a fourth window of opportunity: the appointment of a new personal envoy of the UN Secretary-General for Western Sahara, the American Christopher Ross, and the election of Barack Obama as President of the United States; while these changes represented a source of uncertainty for Morocco, they were viewed as an opportunity by the Sahrawi camp. Domestically, a dramatic tightening up was observed in Moroccan security control and rhetoric towards the Western Sahara population in response to unprecedented inter-Sahrawi reconnection between this periphery and the Tindouf centre. The first 'official' visit by seven Sahrawi pro-independence figures from the occupied territory to the Tindouf refugee camps in September $2009^{x}$ confirmed and formalized their equal recognition (in the sense of respect) by the Polisario Front. The Rabat centre's repressive turn and the ensuing contraction of public space were explicitly reflected in Mohammed VI's warning on the anniversary of the Green March (6 November): '(...) There is no more room for ambiguity or duplicity: either a citizen is Moroccan or he is not. (...) Either one is a patriot or one is a traitor' (Mohammed VI, 2009). ${ }^{\mathrm{xi}}$ The most immediate consequence was the crisis that erupted in mid-November when the Moroccan authorities refused to allow Aminatou Haidar (CODESA) to enter Laayoune on her return from a trip abroad, expelling her to the Canary Islands (Spain). Her hunger strike challenging her deportation was not only successful in prompting U.S. diplomatic intervention and reversing the Moroccan decision, but also highly profitable in terms of international recognition since it brought the internal Sahrawi activists an extraordinary level of external attention (cognitive recognition) and recognition in the form of empathy.

\section{0-11: Local and Arab Springs}

The fifth and last turning point in this chronology can be associated with the protest cycle of the Sahrawi camp of Gdeim Izik in October-November 2010 and the subsequent regional political transformations following the Arab Spring. Some international commentators such as Noam Chomsky went so far as to argue that peripheral Gdeim Izik had been the first chapter of the Arab Spring (Errazzouki, 2012), while others maintained that the Arab Spring did not affect Western Sahara, judging by the 'semblance of stability and calm' that prevailed there for some time after this protest cycle (Boukhars, 2012: 4-5). The latter assessment, however, underestimates three issues which closely linked Gdeim Izik to the Arab Spring and which will be discussed below: first, the similarity of demands and type of activism of Gdeim Izik with those of other Arab Spring protests; second, the significance of Gdeim Izik for the Moroccan Arab Spring and vice versa; and third, the use of the Arab Spring by Sahrawi activists as a way of framing their ongoing protests in order to garner international attention and recognition.

The camp in the outskirts of Laayoune was originally set up by a group of disgruntled Sahrawi youths and unemployed graduates as a reaction to the irregular distribution of hundreds of plots of land for construction by the city council, which was criticized as having clientelist and electoral purposes (in the run-up to local elections in 2009). In the middle of a restrained but fierce power struggle between the 'wilaya' (provincial administration) and the Laayoune city council, not only did the 'wali' (provincial governor) first encourage unrest against the mayor, but he also later turned a blind eye to the rapid expansion of the camp, thus creating an unexpected and precious political opportunity for protest at local level. The number of 'khaimat' (tents) and demonstrators swiftly multiplied. ${ }^{\text {xi }}$

The camp founders cautiously avoided displaying flags or giving it an explicit nationalist or proindependence flavour, although they linked their complaints concerning housing and employment to alleged discrimination against 'true Sahrawis' indigenous to the territory. The Moroccan Ministry of the Interior agreed to negotiate with the protesters' Dialogue Committee and a basic agreement was reached which addressed their socioeconomic demands. However, the limit of politicization seemed 
to have been exceeded and the camp was forcibly dismantled overnight on the following day (López García, 2011). The justification provided by Rabat authorities was, as stated in a parliamentary report, that 'the instrumentalization of social demands served outside political agendas seeking to generate violence and thus internationalize and perpetuate the camp' (Au Fait Maroc, 13 January 2011). . $^{\text {iii }}$ This intervention by the security forces provoked chaos, rioting and violence which spread to the city of Laayoune, resulting in 13 casualties (11 Moroccan policemen), acts of vandalism and reprisals between Sahrawis and Moroccans. The 'fragile coexistence' between the two communities appeared to have been broken by mounting 'ethnic tensions' (Gómez Martín, 2012). Thus, while the Gdeim Izik protest was similar to other Arab Spring protests in the appearance of the demands (socioeconomic grievances which seemed quickly 'politicized') $)^{\text {xiv }}$ and the forms of collective action (the 'occupy' tactic), it ended up reinforcing the unique nature of the conflictual context within which it took place.

At the same time, peripheral Gdeim Izik arguably played an indirect role in the Arab Spring in the Rabat centre. Sahrawi activists did not get involved in the pro-democracy protests organized by the 20 February Movement in Morocco in 2011, which represents a major difference and draws a dividing line with the behaviour of more indisputably 'Moroccan' peripheries such as the Rifian one (Suárez Collado, this volume). Conversely, the 20 February Movement did not engage with the Western Sahara issue in its political agenda because of its highly sensitive and divisive nature. However, if only as a pretext, the process of accelerated constitutional reform launched by Mohammed $\mathrm{VI}$ in response to new domestic and international pressures was officially justified by the long-promised process of 'advanced regionalization', which in turn largely resulted from the Sahara autonomy project and growing unrest in Western Sahara. A Consultative Commission on Regionalization (CCR) had been established in January 2010, charged with drafting and submitting this regionalization project to the King. Nonetheless, neither the new constitution approved by referendum in July 2011 (Theofilopoulou, 2012) nor the CCR plan (Interview IV, 2013), ${ }^{\mathrm{xV}}$ which soon became deadlocked, brought about substantial institutional changes beyond the declaratory effect.

Conversely, the 2011 reform at the Rabat centre that had a more concrete impact on the ground in the Western Sahara periphery was the transformation of the old Consultative Council on Human Rights (CCDH) into the National Council on Human Rights (CNDH), which was formally more independent and prepared to propose measures towards the equal recognition of rights (respect) for the Sahrawis. The first recommendations of the new body included the grant of a royal pardon to 190 prisoners considered to be political, including Sahrawi pro-independence activists. Furthermore, the CNDH set up regional commissions all over the country, three of which were located in the Western Sahara territory (Boukhars, 2013: 4). The aim was to mitigate the 'problem of lack of intermediaries' between the Moroccan authorities and the Sahrawi population (Interview II, 2013), that is, in centreperiphery relations. When interviewed, the President of the CNDH Regional Commission acknowledged the special situation of dealing with human rights violations occurring within a context of 'political conflict' and emphasized the difficult intermediary role played by his institution, not least since it lacked the power to enforce its own recommendations (Interview XIV, 2013).

Apart from that, the Arab Spring stage in this periphery was characterized by the recovery of previous levels of freedom of movement and a new expansion of public space, following the obstacles faced in 2009 and 2010. An increasing number of delegations of internal Sahrawi activists was able to travel to the Tindouf camps and to international meetings, just as more foreign observers, journalists, nongovernmental organizations (NGOs), parliamentarians and supporters arrived in Laayoune (Gimeno, 2013: 40). Most importantly for the international recognition of internal actors, in November 2012 Christopher Ross became the first personal envoy of the UN Secretary-General for Western Sahara ever to visit the specific territory in dispute - and not only Rabat, Tindouf and Algiers as his predecessors had done (Lakome, 21 December 2012). This generated an extraordinary pride as well as mounting expectations among the activists who met him (Interview VI, 2013; Interview VII, 2013). In all of these interactions, Sahrawi activists appropriated the Arab Spring label and used it as a 
universalistic framing for their protests (Interview VI, 2013; Interview X, 2013), which might have helped them at international level to strengthen the demand to extend the mandate of MINURSO to monitor human rights in both Western Sahara and the refugee camps, as (unsuccessfully) proposed by the U.S. to the UN Security Council in April 2013. Several Sahrawi interviewees of different political persuasions positively stressed the greater, 'never expected' U.S. involvement in these human rights issues. 'The U.S. Embassy knows more about our work than the Moroccan authorities themselves', said the president of the CNDH Regional Commission (Interview XIV, 2013). Thus, the regional Arab Spring context helped Sahrawi activists to increase international recognition for their positions, making up for continuing strain in relations with the Rabat centre.

\section{The capitalization of existing mobilizing structures during the Arab Spring}

This transformed structural context sat well with the type of activism which the transforming Sahrawi movement had followed over the past years, and indeed strengthened it. Two prominent strategies and repertoires of collective action stand out in the recent development of the internal Sahrawi proindependence movement: nonviolent resistance and protests inside the occupied territory on one hand and 'international diplomatic activities' (Taras and Ganguly, 2006: 32) on the other. This was enabled by the availability of pre-existing mobilizing structures within/for this periphery - meso-level groups, organizations and informal networks (McAdam, McCarthy and Zald, 1996: 3) - which can be located on four different levels: Sahrawi civil society operating locally in the peripheral Moroccancontrolled territory itself; the larger transnational inter-Sahrawi sphere also encompassing actors from the Tindouf centre, the Polisario Front and the diaspora; a limited part of civil society and institutional actors from the Rabat centre; and international civil society.

Within the Western Saharan periphery, the basis for the mobilizing structures was provided by civil society organizations which share the characteristic of operating without legal recognition, as their bids for legal status have been irregularly rejected by the Moroccan authorities under different pretexts (Human Rights Watch, 2008: 97-108). This lack of equal status does not mean that their activity is strictly clandestine, but does make them subject to regular harassment and arbitrary repression. Another prevalent trait is the focus on the universalistic sphere of human rights, with the two most relevant human rights organizations being ASVDH and CODESA. ASVDH, which claims to be the civil society organization to develop the broadest grassroots activity in the occupied territory (Interview XVI, 2013), ${ }^{\text {xvi }}$ devotes its everyday work to documenting and spreading information on human rights violations, which is often supplied to foreign NGOs and governments (the annual human rights reports the U.S. State Department regularly acknowledge this source). Therefore, its most significant contribution within the Arab Spring context was a thorough report on the Gdeim Izik events (ASVDH, 2011) which helped to set a Sahrawi narrative on this contested episode and was given credibility and relayed by international NGOs and the media. In the case of the CODESA, the focus was rather placed on 'elite work' (Interview X, 2013) and international advocacy and denunciation, ${ }^{\text {xvii }}$ although a similar report needed also to be drafted on Gdeim Izik (CODESA, 2011).

Beyond the human rights sphere, politically relevant and active internal Sahrawi organizations include the Committee for the Defence of the Right to Self-Determination for the People of Western Sahara (CODAPSO), ${ }^{\text {xiii }}$ the Committee for the Support of the UN Settlement Plan and the Protection of Natural Resources of Western Sahara (CSPRON) and the Trade Union Confederation of Sahrawi Workers (CSTS). CODAPSO and CSPRON share an explicitly 'political' pro-independence stance and an emphasis on (or specialization in) the issue of the Moroccan exploitation of Western Sahara's natural resources, which occupies an increasingly prominent place on the diplomatic agenda of the broader Sahrawi movement and benefits from the effective international support of the NGO Western Sahara Resource Watch (WSRW) (Interview VIII, 2013; Quarante, 2014). Major efforts made by these organizations include the campaigns organized in 2011-12 against the fisheries and agricultural agreements between the EU and Morocco. The trade union CSTS, which was officially created in 2007 
by former mine workers from Fos Boucraa but is open to members from other sectors and unemployed graduates, is also heavily involved in this international 'economic' struggle (Interview XV, 2013).

An effective division of labour exists between all of these groups (focusing on international advocacy, human rights, victims and their families, natural resources, unemployed graduates or other specific social problems) and, besides a dense social fabric and key individual networks, formal coordination occurs between organizations at local level within the so-called 'tansikiyat' (coordination committees). The Laayoune 'tansikiya' is made up of some 15 groups which meet with essentially two purposes: the preparation of joint demonstrations and planning of the reception of foreign delegations (Interview VI, 2013). ${ }^{\text {xix }}$ In fact, both kinds of action have been strategically related in recent years, with local protests being staged to coincide with foreign visits, as well as key diplomatic junctures such as the annual renewal of MINURSO's mandate by the UN Security Council. For example, a significant protest cycle took place in different Western Saharan cities in April-May 2013 not only in protest against the failure to extend MINURSO's mandate to human rights, but also encouraged by the unusual arrival of foreign observers and journalists.

Furthermore, the pro-independence groups from occupied Western Sahara are no longer isolated from the exiled population in the Tindouf centre and the Polisario Front. Technological and communicational factors, and more specifically the spread of mobile phones and internet connections, contributed more than anything to 'breaking the wall' and reducing the distance between this periphery and this centre, as well as with the Sahrawi diaspora. ${ }^{x x}$ This and other increasingly frequent transnational contacts and exchanges of all kinds (human rights associations, trade unions, youth organizations, media, family visits) have arguably helped to consolidate a shared 'Sahrawi political identity and political project' (Barreñada, 2012). At least at the societal level, they have fostered a growing recognition of hitherto peripheral internal Sahrawis by their compatriots in exile in the sense of empathy. Nonetheless, concrete 'political' inter-organizational links with the Polisario remain opaque and ambiguous (Gimeno, 2013: 36). Unlike the Moroccan official discourse which maintains the absolute identity of the external 'enemy' and its domestic 'fifth column' (Interview IV, 2013), activists from internal Sahrawi groups largely emphasized their organizational autonomy. ${ }^{x \times i}$ The bottom line is that there is 'sympathy and harmony on goals' (Interview V, 2013), or a broad identity-driven 'political alignment' (Interview III, 2013), but no organizational or dependency relationship between Sahrawi actors in Laayoune and Tindouf (Interview X, 2013). Despite this, the 2009 visit to Tindouf certainly broke a taboo by officializing the recognition of internal activists by the Polisario. The growing formalization of contacts was to turn into equal participation in political bodies two years later, when the $13^{\text {th }}$ Polisario Popular General Congress, held in Tifariti in December 2011, for the first time officially included a delegation of activists from occupied Western Sahara. ${ }^{x \mathrm{ii}}$

The role played by this transnational inter-Sahrawi network with regard to internal Sahrawi activists in the context of the Arab Spring involved recognition, backup and framing. Different signs of recognition were given in the sense of respect (recognition of equal status) and empathy (recognition through understanding and affection), yet always avoiding esteem (recognition of difference) for the sake of the unity of the larger Sahrawi movement. Backup was visibly provided by the spread of information and the placing of a growing official emphasis on human rights violations and resistance in the occupied territory, which were now established by the Polisario as a major bone of contention with Morocco at diplomatic level, together with the demand to extend MINURSO's mandate to human rights. Although they should not be fully dismissed outright, Moroccan suspicions of material support or funding for internal Sahrawi activism have not been backed by evidence. Framing entailed placing all manifestations of internal Sahrawi activism within the unifying framework of a single Sahrawi nationalist struggle, as happened for the Gdeim Izik protest. 
As regards the interaction between the peripheral internal Sahrawi movement and the Rabat centre, the activists' relations with a limited number of Moroccan, 'Moroccanized' or somehow intermediary actors, placed halfway between Rabat and Laayoune, have also proved to be relevant. Among civil society organizations, the pioneering Moroccan Association for Human Rights (AMDH) stands out as a taboo-breaking exception due to its simultaneous work at Moroccan state level and in the occupied territory, which has however come at the expense of constant internal rifts. The AMDH branch in Laayoune is open to activists of all political persuasions, but is in practice mostly made up of Sahrawis, many of whom combine this membership with parallel engagement with other associations, most notably the CODESA. As a result, it has been subject to official harassment akin to that of pro-independence groups (Interview XI, 2013). In practice, the AMDH is used as a 'node' or interface between Sahrawi and Moroccan civil society, for example, in the context of the follow-up committee on the recommendations of the Equity and Reconciliation Commission (IER) or campaigning against the military trial of 25 Gdeim Izik activists in February 2013.

At institutional level, the main intermediary actor in these centre-periphery relations since the Arab Spring has been the CNDH Regional Commission in Laayoune (Interview XIV, 2013), even though Sahrawi activists perceive their access to this Moroccan consultative body as a double-edged sword. Some of them refuse all cooperation since the CNDH does not meet the international standards for national human rights institutions (Paris Principles) and its Laayoune branch is led by co-opted Sahrawis, while others maintain personal contacts with its officials, recognizing their good faith but limited room for manoeuvre (Interview X, 2013) in securing practical improvements for the human rights situation in the territory (treatment of detainees, prison conditions, replacement of certain security officials). At a more individual level, an also widely recognized 'nodal' or bridging role is that played by former Polisario dissident and member of Moroccan parliament Gajmoula Bint Ebbi (Progress and Socialism Party, PPS) who, despite her involvement in Moroccan institutional politics, is said by some to have 'always been with the Sahrawis' (Interview VI, 2013). Interviewees acknowledged her positive contribution as part of the official team that negotiated with the Gdeim Izik protesters in November 2010, her subsequent bold denunciation of the forcible dismantling of the camp and her personal support for the activists who faced military trials along with their families (Interview I, 2013).

The specific international connections and networks that can be viewed as integral to the mobilizing structures of the internal Sahrawi movement include most notably foreign advocacy groups and NGOs. Some relevant state diplomatic representatives, in particular those of the U.S., British and Swedish embassies in Rabat, have shown a growing willingness to establish direct contact with Sahrawi human rights activists. However, their job is largely limited to that of observers or interlocutors. More active or overt support work is carried out at the level of civil society through international networks which partially overlap but do not conflate themselves with those backing the Polisario and the Tindouf refugees. The more visible and effective partners nowadays are the international human rights organizations Amnesty International and Human Rights Watch, the U.S.based Robert F. Kennedy Center for Justice and Human Rights (RFK Center) and the network Western Sahara Resource Watch (WSRW). These advocacy groups serve as interfaces between local activists and international institutions, and lobby in three crucial arenas: the UN Human Rights Council (HRC), the U.S. Administration and Congress, and the European Parliament.

For instance, CODESA co-drafted with the RFK Center and five other international organizations a joint report on the human rights situation in Western Sahara which was submitted to the 'troika' in charge of the HRC's Universal Periodic Review of Morocco in May-June 2012. ${ }^{\text {xiii }}$ At the end of that year, the UN Special Rapporteur on torture Juan E. Méndez visited Morocco and Western Sahara to prepare another report for the HRC which was in no sense indulgent with the Rabat authorities (OHCHR, 22 September 2012). The lobbying of the RFK Center, Amnesty International and Human Rights Watch was instrumental in pushing the Obama Administration and its UN Ambassador to 
circulate a draft Security Council resolution in April 2013 seeking to extend MINURSO's mandate to human rights monitoring (although it was ultimately unsuccessful). One year later, Aminatou Haidar again requested the same measure in the U.S. Congress (SPS, 24 March 2014). As regards WSRW, it played a decisive role in the campaign that ended with the European Parliament's rejection of the protocol of extension of the EU-Morocco fisheries agreement in December 2011 due to, among other things, persistent legal doubts regarding the inclusion of the territorial waters of Western Sahara. ${ }^{\text {xiv }}$ In 2012, another resolution of the European Parliament expressed 'concern at the deterioration of human rights in Western Sahara' and called for the 'release of all Sahrawi political prisoners' (European Parliament, 2012).

\section{Outcomes and conclusions}

Assessments of the results to date of the internal Sahrawi pro-independence movement's domestic and international strategies vary greatly depending on the point of view. As in the cases of most of the peripheries addressed in this special issue, the outcomes seem meagre from a structural and 'objective', ultimately external perspective (Huber and Kamel, this volume). Protests in occupied Western Sahara have certainly not led to better socioeconomic conditions or greater political autonomy for the territory, nor have they increased the chances of a global resolution of the conflict according to these actors' preferences (self-determination) in the international diplomatic sphere. The Gdeim Izik protest and the subsequent Arab Spring developments stopped short of changing the foundations of Moroccan regional and local governance. Neither the new 2011 constitution nor the regionalization project that accompanied it at the Rabat centre brought about substantial institutional changes. The reform of the Political Parties Act approved in October 2011 did not lift the existing ban on the formation of parties on an ethnic or regional basis. The below-average abstention rates recorded in these 'southern provinces' in 2011 in both the July constitutional referendum and the November legislative elections could well be used to legitimize the status quo (Boukhars, 2012: 4-5).

Nonetheless, there is also some room for optimism, as the international pressure on the Moroccan authorities obtained by internal Sahrawis has lately brought about some tangible changes in centreperiphery relations. As recently confirmed by leaked confidential documents of the Moroccan diplomacy, President Obama put forward three specific demands to King Mohammed VI during their meeting in Washington in November 2013: to put an end to military trials for civilians, to allow the UN High Commissioner for Human Rights to visit Western Sahara and to legalize Sahrawi associations such as ASVDH and CODESA. ${ }^{\times x V}$ Steps towards the fulfilment of the first two requests were taken in March and May 2014, respectively (Yabiladi, 14 March 2014; OHCHR, 29 May 2014). As regards the legalization of associations, it was the subject of a recommendation by the $\mathrm{CNDH}$ according to a trial balloon issued in late 2013 (EFE, 20 November 2013), but it has not materialized to date.

The strategies of the internal Sahrawis during the Arab Spring appear to be most successful when one considers these actors' 'subjective' accounts and the extent to which they perceive that their selfdescriptions or self-interpretations have been acknowledged and validated by external others. That is to say, their outcomes as a periphery need to be judged first and foremost in terms of the recognition gained - or seized - from three significant others: the Moroccan state, the Polisario Front and the international community. The Rabat centre might have been the most prolific promoter of policies of recognition towards this periphery, from equal human rights initiatives to recognition of difference and material reparations. However, as they have taken place against the backdrop of structural misrecognition of the Sahrawis entailing an essential lack of respect or equal status (human rights violations, repression of pro-independence activists, no legal recognition for Sahrawi civil society organizations), these partial actions have been flawed by an inherent mismatch with the self-identity of the target actors. They have thus been largely ineffective if not ultimately counterproductive for Moroccan interests. 
Conversely, the internal Sahrawi activists have achieved growing cognitive recognition (attention) and respect (equal status) from the Tindouf centre and relevant international actors, including the UN and the U.S., as well as considerable empathy from inter-Sahrawi and foreign civil society. Cautious optimism prevailed in the responses provided during the author's interviews, based above all on the movement's successes in the Arab Spring context in making its voice heard and achieving a certain impact in international fora, hand in hand with its international support and advocacy networks. However excessive the activists' expectations of future influence on the U.S. Administration and the European Parliament may seem, their 'subjective' views do reveal the invaluable significance of these international connections and achievements, if only for their coming-into-existence and the assertion of a long-denied identity. This suggests some parallels with the internationalisation strategy followed by the Palestinians since 2011, with the UN statehood bid as the most emblematic measure, although the extent of this inspiration is qualified by the Sahrawis' more peripheral position, lack of an internationally recognized state-like 'authority' and less developed foreign networks.

While the larger and complex reconstruction of Sahrawi communal and/or national identity which appears to have been underway since the turn of the millennium falls beyond the scope of this article, it seems clear that each of the above-mentioned forms of (mis)recognition has had a distinct impact on the dynamics of identity-construction of the internal Sahrawis. Most conspicuously, the Moroccan (depoliticized) recognition of Sahrawi cultural difference has accidentally fostered an ethnicization that transcends colonial territorial demarcations, while the international recognition of internal Sahrawi civil society has encouraged the latter to concentrate on universalistic issues such as human rights and the exploitation of the natural resources of the occupied territory, even more so since 2010-11 in order to accommodate and capitalize on the Arab Spring framing.

Altogether, this article has shown that the emergence and empowerment of internal Sahrawi proindependence activism has to be seen in the context of varying sets of opportunity structures actively seized by this peripheral movement over the last two decades through the symbiotic combination of domestic nonviolent resistance and international 'diplomatic' activities. The Arab Spring has offered the latest window of opportunity in this chronology and Sahrawis have successfully been able to frame their protests within this paradigm. Building on comparatively rich mobilization structures at local, inter-Sahrawi, Moroccan and international level, internal Sahrawis have been relatively more effective than other peripheries treated in this volume at garnering international recognition, which has helped to strengthen and crystallize their own identity.

\section{Acknowledgements}

In memory of Lahcen Moutik who passed away in December 2013, a few months after our interview. Thanks to Miguel Hernando de Larramendi and Michal Natorski for their feedback on the empirical work and the theoretical hints, to the editors of this special issue and to all of the interviewees from Laayoune and Rabat (also those who asked for confidentiality).

\section{References}

Amnesty International (2010) Broken Promises. The Equity and Reconciliation Commission and its Follow-up (London: Amnesty International).

Association Sahraouie des Victimes des Violations Graves des Droits de I'Homme [ASVDH] (2011), Rapport de l'ASVDH sur le campement de Gdeim lzik et les événements qui ont suivi son démantèlement (Laayoune: ASVDH).

Azar, E. E. (1990) The Management of Protracted Social Conflict: Theory and Cases (Aldershot: Dartmouth). 
Barreñada, I. (2012) Asociacionismo y cuestión nacional en el Sáhara Occidental, Revista de Estudios Internacionales Mediterráneos, 13.

Bogaert, K. (2014) The Revolt of Small Towns: The Meaning of Morocco's History and the Geography of Social Protests, Review of African Political Economy.

Boukhars, A. (2012) Simmering Discontent in the Western Sahara, Carnegie Endowment for International Peace/Carnegie Middle East Program, March.

Boukhars, A. (2013) Western Sahara: Beyond Complacency, FRIDE, Policy Brief 163, September.

Colectivo de Defensores de Derechos Humanos Saharauis [CODESA] (2011), Campamento Gdeim Izik (Laayoune: CODESA).

Dann, N. (2014) Nonviolent Resistance in the Western Sahara, Peace Review, 26(1), pp. 46-53.

Darbouche, H. and S. Colombo (2011) The EU, Civil Society and Conflict Transformation in Western Sahara: The Failure of Disengagement, in: N. Tocci (ed.) The European Union, Civil Society and Conflict (London/New York: Routledge), pp. 126-146.

Diani, M. and D. McAdam (eds.) (2003) Social Movements and Networks. Relational Approaches to Collective Action (Oxford: Oxford University Press), pp. 1-18.

Errazzouki, S. (2012) Chomsky on the Western Sahara and the 'Arab Spring', Jadaliyya, 30 October.

European Parliament (2012) Resolution on the Annual report on human rights and democracy in the world 2011 and the European Union's policy on the matter, 13 December.

Fraser, N. and A. Honneth (2003) Redistribution or Recognition? A Political-Philosophical Exchange (London/New York: Verso).

Gimeno, S. (2013) Situación de los derechos civiles y políticos en el Sáhara Occidental: de 1999 a la actualidad, Seminario de Investigación para la Paz, 30 May.

Gómez Martín, C. (2012) Sahara Occidental: quel scénario après Gdeim Izik?, in: L’Année du Maghreb 2011 (Paris: CNRS), pp. 259-276.

Hernando de Larramendi, M. (2008) Intra-Maghrebi Relations. Unitary Myth and National Interests, in: Y. H. Zoubir and H. Amirah Fernández (eds.) North Africa: Politics, Region, and the Limits of Transformation (London/New York: Routledge), pp. 179-201.

Honneth, A. (1996) The Struggle for Recognition: The Moral Grammar of Social Conflicts (Cambridge, MA: MIT Press).

Human Rights Watch (2008) Human Rights in Western Sahara and in the Tindouf Refugee Camps. Morocco/Western Sahara/Algeria (New York: Human Rights Watch).

Lakmahri, S. and A. Tourabi (2013) Le Maroc a-t-il échoué au Sahara?, Zamane, 28, pp. 34-41.

Lindemann, T. (2010) Causes of War: The Struggle for Recognition (Colchester: ECPR).

Lindemann, T. and E. Ringmar (eds.) (2012), The International Politics of Recognition (Boulder/London: Paradigm).

López García, B. (2011) Sahara-Marruecos: el miedo a la autonomía, Política Exterior, 139, pp. 38-46. Martín Beristain, C. and E. González Hidalgo (2012) El oasis de la memoria. Memoria histórica y violaciones de Derechos Humanos en el Sáhara Occidental (San Sebastián: Universidad del País Vasco/Hegoa).

McAdam, D., J. D. McCarthy and M. N. Zald (eds.) (1996) Comparative Perspectives on Social Movements: Political Opportunities, Mobilizing Structures, and Cultural Framings (Cambridge: Cambridge University Press).

Mohammed VI (2009) Discours de SM le Roi à la Nation à l'occasion du $34^{\mathrm{e}}$ anniversaire de la Marche Verte, available at: http://www.maroc.ma/fr/discours-royaux/discours-de-sm-le-roi-\%C3\%AO-lanation-\%C3\%A0-loccasion-du-34\%C3\%A8me-anniversaire-de-la-marche.

Mohsen-Finan, K. (1997) Sahara Occidental. Les enjeux d'un conflit régional (Paris: CNRS).

Mundy, J. (2007) Western Sahara between Autonomy and Intifada, Middle East Report Online, 16 March.

Mundy, J. and S. Zunes (2014) Western Sahara. Nonviolent Resistance as a Last Resort, in: V. Dudouet (ed.) Civil Resistance and Conflict Transformation: Transitions from Armed to Nonviolent Struggle (London/New York: Routledge), pp. 20-44. 
Pace, M. (2013) An Arab 'Spring' of a Different Kind? Resilience and Freedom in the Case of an Occupied Nation, Mediterranean Politics, 18(1), pp. 42-59.

Quarante, O. (2014) Si riche Sahara occidental, Le Monde Diplomatique, March.

Ramsbotham, O., T. Woodhouse and H. Miall (2011) Contemporary Conflict Resolution. The Prevention, Management and Transformation of Deadly Conflicts ( $3^{\text {rd }}$ ed.) (Cambridge: Polity).

Romano, D. (2006) The Kurdish National Movement. Opportunity, Mobilization and Identity (Cambridge: Cambridge University Press).

San Martín, P. (2005) Nationalism, Identity and Citizenship in the Western Sahara, The Journal of North African Studies, 10(3-4), pp. 565-592.

Smith, L. E. (2005) The Struggle for Western Sahara: What Future for Africa's Last Colony?, The Journal of North African Studies, 10(3-4), pp. 545-563.

Solà-Martín, A. (2007) The Western Sahara Cul-de-Sac, Mediterranean Politics, 12(3), pp. 399-405.

Stephan, M. J. and J. Mundy (2006) A Battlefield Transformed: From Guerrilla Resistance to Mass

Nonviolent Struggle in the Western Sahara, Journal of Military and Strategic Studies, 8(3), pp. 1-32.

Taras, R. and R. Ganguly (2006) Understanding Ethnic Conflict: The International Dimension ( ${ }^{\text {rd }}$ ed.) (New York: Longman).

Tarrow, S. (2003) Power in Movement: Social Movements and Contentious Politics (2 ${ }^{\text {nd }}$ ed.) (Cambridge: Cambridge University Press).

Taylor, C. (1994) Politics of Recognition, in: C. Taylor and A. Gutmann (eds.) Multiculturalism: Examining the Politics of Recognition (Princeton: Princeton University Press), pp. 25-73.

Theofilopoulou, A. (2012) Morocco's New Constitution and the Western Sahara Conflict. A Missed Opportunity?, The Journal of North African Studies, 17(4), pp. 687-696.

Thompson, S. (2006) The Political Theory of Recognition: A Critical Introduction (Cambridge: Polity).

Vairel, F. (2006) L'Instance Équité et Réconciliation au Maroc: lexique international de la réconciliation et situation autoritaire, in: S. Lefranc (dir.) Après le conflit, la réconciliation? (Paris: Michel Houdiard), pp. 229-253.

Veguilla, V. (2009) L'articulation du politique dans un espace protestataire en recomposition. Les mobilisations des jeunes Sahraouis à Dakhla, in: L'Année du Maghreb 2008 (Paris: CNRS), pp. 95-110.

Zoubir, Y. H. and K. Benabdallah-Gambier (2004) Morocco, Western Sahara and the Future of the Maghrib, The Journal of North African Studies, 9(1), pp. 49-77.

Zunes, S. and J. Mundy (2010) Western Sahara: War, Nationalism and Conflict Irresolution (New York: Syracuse University Press).

\section{Interviews}

Interview I. Abderrahman Zayou, Sahrawi activist, member of the Dialogue Committee of the Gdeim Izik protest camp subjected to military trial. Rabat, 5 June 2013.

Interview II. Rahal Boubrik, director of the Centre des Études Sahariennes and professor of Sociology, University Mohammed $\mathrm{V}$ Rabat, advisor of the president of the National Council for Human Rights (CNDH). Rabat, 6 June 2013.

Interview III. Lahcen Moutik, former Sahrawi leader of the Forum for Truth and Justice (FVJ). Rabat, 6 June 2013.

Interview IV. Abdelhamid El Ouali, professor of International Law and International Relations, University Hassan II Casablanca, and former member of the Consultative Commission on Regionalization (CCR). Casablanca, 7 June 2013.

Interview V. Brahim Elansari, research assistant at Human Rights Watch (Middle East and North Africa Division). Rabat, 7 June 2013.

Interview VI. Elghalia Djimi and Brahim Sabbar, respectively vice-president and secretary-general of the Sahrawi Association of Victims of Gross Human Rights Violations Committed by the Moroccan State (ASVDH). Laayoune, 9 June 2013.

Interview VII. Mohammed Daddach, president of the Committee for the Defence of the Right to SelfDetermination for the People of Western Sahara (CODAPSO). Laayoune, 9 June 2013. 
Interview VIII. Ali Salem Babeit, Abdelhay Toubali and Salha Boutenghiza, respectively vice-president and members of the Committee for the Support of the UN Settlement Plan and the Protection of Natural Resources of Western Sahara (CSPRON). Laayoune, 10 June 2013.

Interview IX. Hayat Hatari and Salha Boutenghiza, volunteer reporters of RASD TV in Laayoune. Laayoune, 10 June 2013.

Interview X. Ali Salem Tamek, Larbi Messaoud, Lidri Hussein, Mohamed Salem Lakhal and Mohamed Fadel Gaoudi, respectively vice-president, secretary-general and members of the secretariat of the Collective of Sahrawi Defenders of Human Rights (CODESA). Laayoune, 10 June 2013.

Interview XI. Hamoud Iguilid, president of the Laayoune section of the Moroccan Association of Human Rights (AMDH). Laayoune, 10 June 2013.

Interview XII. Group of former political prisoners arrested during the 2005 'Intifada'. Laayoune, 11 June 2013.

Interview XIII. Mohamed Boukhaled and Mohamed Lehbib Ergueibi, Sahrawi lawyers and defence counsels of many activists. Laayoune, 11 June 2013.

Interview XIV. Mohammed Salem Cherkaoui, president of the Regional Commission of LaayouneSmara of the National Council on Human Rights (CNDH). Laayoune, 12 June 2013.

Interview XV. Sidi Ahmed Eddia, secretary-general of the Trade Union Confederation of Sahrawi Workers (CSTS), and four other members of its executive board. Laayoune, 12 June 2013.

Interview XVI. Brahim Dahane, president of the Sahrawi Association of Victims of Gross Human Rights Violations Committed by the Moroccan State (ASVDH). Laayoune, 12 June 2013.

\footnotetext{
'See the classification of conflicts in Ramsbotham, Woodhouse and Miall (2011: 76).

ii Sahrawi national liberation movement fighting against Moroccan presence in Western Sahara and recognized by the UN General Assembly in 1979 as 'the representative of the people of Western Sahara'.

iii In this article the term 'internal Sahrawi' is applied to civil society, organizations, groups, activists and leaders operating inside Western Sahara occupied territory, which self-define as 'Sahrawi' and broadly favour independence, in order to emphasize the distinction between them and their counterparts in the refugee camps of Tindouf or the diaspora, which is central to the argument. For an overview of Sahrawi civil society in the Tindouf camps, see Darbouche and Colombo (2011).

iv A period of heightened state violence against political opposition under the reign of Hassan II, from the 1960s to the 1980s.

${ }^{v}$ The Moroccan Association of Human Rights (AMDH) had also opened a pioneer office there shortly before, but at that time only included members of Moroccan origin. Viewed as increasingly menacing by the Rabat authorities, the FVJ-Sahara was eventually dissolved by the Laayoune Court of First Instance in June 2003 on the grounds that it used 'human rights as a cover to pursue both violent and diplomatic "separatist" activities' (Human Rights Watch, 2008: 99-101).

${ }^{\mathrm{vi}}$ The Baker Plan II represented a polished proposal for a mixed solution combining a stage of transitory autonomy with a final referendum on self-determination.

vii Not only was the Western Sahara territory excluded from the collective reparation programme designed for some regions, but also the public hearing scheduled in Laayoune was eventually cancelled (Vairel, 2006: 243). 'The IER rather than addressing the particular breadth of violations suffered by Sahrawis, increased their feelings of marginalization' (Amnesty International, 2010: 269-275).

viii In late May, a small rally in Laayoune opposing the transfer of a Sahrawi prisoner to Agadir resulted in an unprecedented cycle of demonstrations, repression and riots after it was violently broken up by the Moroccan police (Mundy, 2007; Smith, 2005: 546, 558; Interview XII, 2013).

ix The Autonomy Plan was to be submitted to the UN in March-April 2007, and was backed up by an ambitious diplomatic offensive.

${ }^{x}$ The meeting organized in September 2009 stemmed from an initiative of internal groups later adopted by the Polisario (Interview III, 2013), which resulted in the arrest of the activists on their return to Laayoune, amid a climate of Moroccan patriotic outrage. In spite of the obstacles faced, this ground-breaking visit set a precedent and was to become the first of a handful of journeys to Tindouf in subsequent years.

${ }^{x i}$ This address was highlighted as a pivotal fact almost unanimously in the author's interviews (for example Interview XIII, 2013).
} 
xii Some estimates refer to around 6,500-8,000 tents and 20,000-25,000 protesters (Gómez Martín, 2012).
xiii See also Lakmahri and Tourabi (2013).
xiv The distinction between socioeconomic and 'political' protest is widespread in the literature on the Arab Spring and social movements in this region (Bergh and Rossi-Doria, this volume). For a critique of the 'hierarchy of struggles' implicit within this dichotomy, see Bogaert (2014: 2-4) and, in the case of Western Sahara, see Veguilla (2009).

${ }^{x v}$ A draft regionalization bill following the recommendations of this Commission was presented by the Moroccan government in the summer of 2014.

${ }^{x v i}$ Set up in 2005 by former members of the Coordination Committee, ASVDH is characterized by its selfdefinition as an 'association of victims'. Although all legalization procedures established by the Moroccan Association Law were followed, the Moroccan authorities continued to treat it as an 'unrecognized' organization. ASVDH has sections in several cities of Western Sahara as well as southern Morocco (Barreñada, 2012), but its failure to secure normalization has prevented it from having a proper membership record, so in principle 'any victim can consider himself/herself as a member' (Interview VI, 2013).

xvii CODESA was formally created in 2007 as the successor of the former FVJ-Sahara, although the Moroccan authorities prevented its founding congress from being held and refused to legalize it, arguing that its principles undermined the state's 'territorial integrity' and that its focus on the Sahrawi population amounted to 'discrimination'. Due to this legal situation, the only internal body established within the organization is a 14member secretariat (bureau). The three tasks performed are assisting the victims of violations to file both lawsuits and complaints with the $\mathrm{CNDH}$, preparing annual and thematic reports concerning the human rights situation in Western Sahara, and carrying out international advocacy work (Interview X, 2013).

xviii CODAPSO was founded in April 2005 by the renowned Mohammed Daddach, the longest Sahrawi prisoner of war held by Morocco (1976-2001) and former Polisario Front fighter, in response, he said, to 'the Moroccan propaganda regarding the Autonomy Plan' (Interview VII, 2013).

${ }^{x i x}$ Another local 'tansikiya' was operating in the city of Smara at the time of Christopher Ross' visit in October 2013. The only relevant group that prefers to stay out of these inter-organizational networks is the CODESA (Interview X, 2013), which suggests a subtle strategic and tactical cleavage with the other leading organization, the ASVDH. The opposition between grassroots activity vs. 'elite work' and promotion vs. rejection of local inter-organizational coordination roughly describe the acknowledged differences between their respective approaches. This is coupled with some inevitable competition for domestic leadership and international attention and recognition at both individual and organizational level, even though in general cooperation visibly prevails over tensions or fragmentation.

${ }^{x x}$ In the early 2000s, the use of mobile phones started to become widespread, rendering futile the previous restrictions on international calls from landlines in the occupied territory, while the internet entered the scene with the appearance of the first cybercafés. Later on, in 2009, another powerful vehicle for inter-Sahrawi reconnection in the media sphere came with the launch of regular RASD TV broadcasts from Tindouf, which soon became the most widely watched channel in the Moroccan-controlled Western Sahara (Interview IX, 2013).

${ }^{x x i}$ Two vital yet somehow contradictory discursive red lines were at stake here for a mixture of pragmatic/tactical and principled/identity reasons. On the one hand, any questioning of the unity and unanimity of the broader Sahrawi movement is avoided as being detrimental to the nationalist struggle and the preservation of the legal self-determination framework, to which pro-independence Sahrawis of all sides remain attached. On the other hand, any acknowledgement of integral connections with the Polisario would play into the hands of the Moroccan authorities, giving them a pretext to justify harsher repression of internal activists. An additional more identity-related explanation is that the internal groups' own search for recognition also discourages them from blending themselves in with the Polisario.

xxii The 54 members of this delegation, who belonged to organizations such as CODESA, CODAPSO, ASVDH and CSPRON, were involved in the so-called Commission of the Occupied Territories and the Intifada of Independence (SPS, 20 December 2011), and participated in all votes on an equal footing with the other congress delegates (Interview VII, 2013; Interview VIII, 2013).

xxiii http://www.cihrs.org/wp-content/uploads/2012/05/RFK-Center-Joint-UPR-Submission-Morocco.pdf.

xxiv However, a new fisheries protocol was signed and adopted by the European Parliament and Council at the end of 2013.

${ }^{x x v}$ See, for example, the letter from the Moroccan Ministry of Foreign Affairs to King Mohammed VI, 3 February 2014, available at http://www.4shared.com/web/preview/pdf/Um3bkoJvce. 